\title{
Laury Silvers. A Soaring Minaret: Abu Bakr Al- Wasiti and the Rise of Baghdadi Sufism
}

Ève Feuillebois-Piérunek

\section{(2) OpenEdition \\ 12 Journals}

Édition électronique

URL : http://journals.openedition.org/abstractairanica/40326

DOI : 10.4000/abstractairanica.40326

ISSN : 1961-960X

\section{Éditeur :}

CNRS (UMR 7528 Mondes iraniens et indiens), Éditions de l'IFRI

\section{Édition imprimée}

Date de publication : 1 décembre 2013

ISSN : 0240-8910

\section{Référence électronique}

Ėve Feuillebois-Piérunek, «Laury Silvers. A Soaring Minaret: Abu Bakr Al-Wasiti and the Rise of Baghdadi Sufism », Abstracta Iranica [En ligne], Volume 32-33 | 2013, document 379, mis en ligne le 01 juillet 2016, consulté le 26 septembre 2020. URL : http://journals.openedition.org/abstractairanica/ 40326 ; DOI : https://doi.org/10.4000/abstractairanica.40326

Ce document a été généré automatiquement le 26 septembre 2020.

Tous droits réservés 
Laury Silvers. A Soaring Minaret: Abu Bakr Al-Wasiti and the Rise of Baghdadi Sufism

Ève Feuillebois-Piérunek 


\section{RÉFÉRENCE}

Laury Silvers. A Soaring Minaret: Abu Bakr Al-Wasiti and the Rise of Baghdadi Sufism. New York, State University of New York Press, 2010, 142 p.

1 Élève de Junayd et de Nūrī, Abū Bakr al-Wāsițī est le premier à implanter la tradition du soufisme bagdadien au Khorasan. Il développe une théologie sophistiquée en accord avec le courant traditionnaliste des Ahl al-Hadit et anticipe des discussions importantes dans les domaines de la métaphysique et de l'éthique. Il est aussi l'un des premiers soufis à composer un commentaire du Coran, commentaire dont s'inspirera Sulamī.

2 L'ouvrage se compose de deux grandes parties. La première, historique, esquisse l'histoire de la transmission du soufisme au Khorasan, la synthèse établie au $\mathrm{XI}^{\mathrm{e}} \mathrm{s}$. par Sulamī entre soufisme bagdadien et malāmatiyya khorasanienne, et la contribution du soufisme khorasanien au développement des ordres soufis au XII ${ }^{\mathrm{e}}$ siècle.

La deuxième partie analyse la pensée théologique et mystique de Wāsițī: sa compréhension de la nature de la réalité divine qu'il faut connaître pour s'y conformer, l'équation complexe entre transcendance et attributs divins (la création existe et se maintient par les Attributs; Dieu se tient dans Sa création et agit à travers elle), la théorie des actes (ceux-ci n'ont pas de réalité en eux-mêmes et sont éthiquement neutres ; c'est leur provenance divine qui les rend positifs et efficaces).

4 Complété par une bibliographie et des index, ce petit livre est un premier pas vers la connaissance de cet auteur important par le rôle de charnière qu'il joua entre spiritualité bagdadienne et mystique khorasanienne.

\section{AUTEURS}

\section{ÈVE FEUILLEBOIS-PIÉRUNEK}

Université Sorbonne Nouvelle-Paris 3, Mondes iranien et indien, Paris 